\title{
Relationship between the Star and the Hotel Service Guarantees of Customer Satisfaction
}

\author{
Aslinda Mohd Shahril ${ }^{1}$, Yuhanis Abdul Aziz ${ }^{2}$, Mohhidin Othman ${ }^{2} \&$ Jamil Bojei $^{2}$ \\ ${ }^{1}$ Faculty of Hotel and Tourism Management, Universiti Teknologi Mara, Malaysia \\ ${ }^{2}$ Universiti Putra Malaysia, Malaysia \\ Correspondence: Aslinda Mohd Shahril, Faculty of Hotel and Tourism Management, Universiti Teknologi Mara, \\ Malaysia. E-mail: lindashahril74@gmail.com
}

Received: February 5, 2015

Accepted: February 17, 2015

Online Published: March 25, 2015

doi:10.5539/ijef.v7n4p82

URL: http://dx.doi.org/10.5539/ijef.v7n4p82

\begin{abstract}
Earlier research on service guarantees have evidenced the importance of service guarantees, their positive relationship with the firm, enhance customer's perception and act as a tool to the service quality. The objectives of this study were to examine the relationship between hotel star, service guarantees and customer satisfaction in the luxury hotels in Malaysia. The study wished to explore if hotel star has significant relationship with employee perception and service guarantees and employee perception toward customer satisfaction. The study investigates these relationships from the front-line hotel employee perspective. The study conducted survey and delivered the questionnaires to the front-line employees. The findings indicated that hotel star has strong influence on service guarantees offered by hotels and it has moderate relationship with customer satisfaction. The result showed that customer has almost same level of satisfaction when staying at four or five star hotels due to similar service offerings. Based on the findings, implications for hotel and customers are discussed and further research is suggested.
\end{abstract}

Keywords: service guarantees, customer satisfaction, front-line hotel employee, hotel sector

\section{Introduction}

A service guarantee is a tool for promoting service quality which consists of few strong points (Hart, 1988). It encourage organization to identify service failure, focus on customer needs, clear company's performance standard and guideline and builds customer loyalty and increase sales (Zeithaml, Bitner, \& Gremler, 2009; Gronroos, 2007; Lovelock \& Wirtz, 2007; Hart, 1988). 'Excellent service is a profit strategy for an organization' (Berry, Parasuraman, \& Zeithaml, 1994, p. 32) and they highlighted that service quality has close relationship with company's growth, revenue and customer satisfaction. Therefore, to achieve company's success, clear guidelines to employees and organization ultimate strategy is vital (Firnstahl, 1989).

Service sector, for example, will inevitably involve with service encounters to deliver service and front-line employees have high interaction services with customers. Thus, front-line employees play crucial role to present the organization image and build customer positive perception.

In order for front-line employees to perform as expected by the organization, they must have knowledge on performing the job and clear understanding on company policy provided by the employer. Front-line employees have high interaction with customers on a daily basis and they are likely to represent the organization to customers. The nature of their work allowed the researcher to examine the practice of service guarantees which is quite common in the hotel sector. A review of the literature shows that the focus of studies has predominantly been from customer's perspective rather than employee's perception of service guarantees. The potential correlation between service guarantees and employee's perception is interested to be explored and this relationship is being examined in this study.

\section{Objectives and Statement of Hypotheses}

Bearing in mind the importance of having service guarantees in this customer orientation era, the study findings could help the hotel sector in delivering efficient service guarantees and achieving an optimal continuous service improvement among employees. Based on the above objectives and after reviewing the literature, below are the hypotheses of the study: 
H1a: There is a significant difference between hotel star in the perception among employees towards service guarantees.

H1b: There is a significant difference between hotel star in the perception among employees towards customer satisfaction.

\section{Literature Review}

A service guarantee is viewed as the company signaling to service quality (Wirtz, Kum, \& Lee, 2000) while Liden and Skalen (2004) assumed that guarantees act as service development process to company. Theorists have proposed service guarantees from multi-approach dimension since its scope is broad (Kashyap, 2001). Some researchers view it as policy and some say that it is a firm promise. Hotels are often associated with guarantees as it covers the essence of service offerings and the courtesy of service employees during the service consumption (McDougall, Levesque, \& Plaat, 1998). Effective guarantee should be meaningful and value to customers, easy to invoke and easy to understand (Hart, 1988). Further, hotel guarantees do not specify on certain attributes but it covers the whole service performance (McDougall et al., 1998). Some hotels known for its guarantees are Hampton Inn and Four Seasons Hotel.

High end or luxury hotels such as four-and five-star hotels are believed to have higher commitment to maintain long-term guest relationship and are committed for customer satisfaction (Kim, Kim, \& Kim, 2009). The genteel client values impeccable service and willing to pay for the comfort provided by this type of hotel thus meaningful service guarantees are very much appreciated by the customers. In hotel sector, appropriate relationship marketing such as offering a meaningful service guarantees is important to form, improve and maintain a sound business relationships with customers. Once the hotel has gain customer trust to service provider, it will give confidence to customer and increase their satisfaction (Kim et al., 2009). Thereby, the study suggest that luxury hotel have a better strategy through service guarantees to signaling firm commitment to deliver high standard of service and to reach customer maximum satisfaction.

Customer satisfaction has been main focus for the firm's because of positive customer behavior from the organization's perspective (Söderlund, 1998). Delivering quality service has become priority in this competitive millennium businesses which in turn will lead to satisfied customer (Shemwell, Yavas, \& Bilgin, 1998). It has been widely acknowledged in the services and marketing literature that customer satisfaction and service quality is undoubtedly are two related core concepts (Jones \& Sasser, 1995; Reichheld \& Sasser, 1990; Spreng, Harrell, \& Mackoy, 1995). Customer's perception on service excellent has been found to increase satisfaction which leads to customer retention and purchase intention (Cronin \& Taylor, 1992; Kandampully \& Suhartanto, 2003; Kivelä \& Chu, 2001; Söderlund, 1998). Particularly, more recent research conducted in hotel setting, specifically luxury hotels suggest that luxury hotel services and customer satisfaction is highly correlated and contributes to the success on hospitality business (Suki, 2012; Li \& Krit, 2012; Guzzo, 2010). Therefore, it is argue that higher level of hotel category has positive relationship with customer satisfaction.

\section{Methodology}

The study sample will be the four-star and five-star hotels that are situated in Peninsular Malaysia. 10 four-star and 10 five-star hotels in Peninsular Malaysia were contacted and the hotel agreed to participate in the research. Stratified sampling was used to determine the hotel population. According to Aaker, Dave and Kumar (2001), stratified sampling can improve the sampling efficiency by increasing the data accuracy.

The list of hotel was obtained from The Tourism Malaysia's Accomodation Directory 2012-2013, which is used to identify hotel organizations to be used in the study. The researcher referred to the directory book year 2012-2013 because it provides the latest list of hotels with all information available at the time data to be collected. At the time research was conducted, such directory book of year 2014-2015 was not available in the Tourism Malaysia Centre, thus using the directory book year 2012-2013 was highly recommended.

These hotels categories were selected as the research site because it serves the purpose of the study whereby this type of hotels are believed to be more committed with customer satisfaction and provide good service. Furthermore, it is assumed that luxury hotel offer service guarantees to their guests, whether it is explicit or implicitly displayed and with or without the knowledge of its guests.

Accordingly, the unit of analysis for the study is the front-line hotel employee from food and beverage and front office department. They were selected since they have high interaction and deal directly with customers. In determining the population of the study, the hotel managers were contacted to gather data on the average number of front-line employee that work at their hotels. Based on the information, the average number of front-line workers in the front office department was about 10 employees, whereas the average number of food and 
beverage department was about 15 employees. Therefore, they form the projected population of the study and calculated as follows:

\section{0 hotels (four-star and five-star) $\times 25$ employees $=500$ employees}

However, a minimum of 108 respondents were sufficient to statistically represent a population of 500 (Krejcie \& Morgan, 1970).

The instrument used was the common measurement behavior with scales and questionnaire method adapted from the work of Hays and Hill (2006), Shahril (2014), Aziz (2007) and Severt (2002) with the reliability or Cronbach's alpha for the questionnaire ranges above 0.8. These researchers work was adapted for this study because of their considerable researches in the field. Furthermore, the researchers feel that the measurement construct developed are suitable for the research design adopted for this study.

\section{Findings and Discussion}

120 copies of the questionnaires were distributed to the participated hotel. From the 120 questionnaires that were distributed, 110 were useable. The respondent's demographic characteristics are presented in the table below:

Table 1. Respondent demographic characteristics

\begin{tabular}{|c|c|c|c|}
\hline Demographic & Characteristics and classification & Frequency & Percentage \\
\hline \multirow[t]{2}{*}{ Gender } & Male & 64 & 58 \\
\hline & Female & 46 & 42 \\
\hline Total & & 110 & 100 \\
\hline \multirow[t]{5}{*}{ Age } & $18-20$ years & 21 & 19 \\
\hline & 21-30 years & 32 & 29 \\
\hline & $31-40$ years & 23 & 21 \\
\hline & $41-50$ years & 25 & 23 \\
\hline & Above 50 years & 9 & 8 \\
\hline Total & & 110 & 100 \\
\hline \multirow[t]{4}{*}{ Race } & Malay & 63 & 57 \\
\hline & Chinese & 12 & 11 \\
\hline & Indian & 20 & 18 \\
\hline & Others & 15 & 14 \\
\hline Total & & 110 & 100 \\
\hline \multirow[t]{4}{*}{ Working experience } & $0-3$ years & 49 & 45 \\
\hline & 4-6 years & 30 & 27 \\
\hline & $7-10$ years & 24 & 22 \\
\hline & Above 10 years & 7 & 6 \\
\hline Total & & 110 & 100 \\
\hline \multirow[t]{5}{*}{ Level of education } & Secondary & 45 & 41 \\
\hline & Certificate & 23 & 21 \\
\hline & Diploma & 32 & 29 \\
\hline & First degree & 5 & 4.5 \\
\hline & Others & 5 & 4.5 \\
\hline Total & & 110 & 100 \\
\hline \multirow[t]{2}{*}{ Department } & Food and beverage & 68 & 62 \\
\hline & Front office & 42 & 38 \\
\hline Total & & 110 & 100 \\
\hline
\end{tabular}

\section{Results of T-Test and ANOVA and SEM}

In this study, the control variables include star rating, gender, age and experience. $\mathrm{T}$ test analysis and one way analysis of variance (ANOVA) was conducted to explore the relationship on the dependent and independent variables.

The analysis was guided based on exploratory analysis. A separate analysis was conducted for each variable. T test was only used when include gender since gender has only two categories; which is male and female; while the other analysis used ANOVA since each of the control variable has more than two categories. 
Table 2. Summary of the effect of control variables for employee study

\begin{tabular}{ccc}
\hline Control Variable & Variable & Sig \\
\hline Hotel star & Service Guarantees & 0.000 \\
Hotel star & Customer Satisfaction & 0.039 \\
\hline
\end{tabular}

As evidenced in Table 1, hotel star have a significant impact on the service guarantees. For example, the results showed a significant value on the impact of star hotel on service guarantees (sig: 0.000). Based on the information provided in Table 1, it is assumed that these control variables have a significant impact on the respective variable. For example, it is predicted that hotel star difference has a significant impact on service guarantees. As mentioned previously, four-and five star hotels were evaluated in this study.

Following the steps taken by Aziz (2007), the control variables (as listed in Table 2) were regressed on their respective dependent variables. This is done in structural model by specifying control variables as one of the predictors where additional new paths are created between the control variables to its dependent variables. For example, the effect of hotel star was regressed on two variables where there were two paths leaving the hotel star to service guarantees and customer satisfaction to examine if hotel category makes a significant different to these two variables.

Initially, the effect of hotel star was regressed on all variables and ANOVA proposed only two significant paths found, that was hotel star to service guarantees and customer satisfaction. The study also tests the relationship in structural model analysis to reconfirm the findings. Similar to the result of ANOVA, the structural model analysis found that hotel star has significant relationship with service guarantees and customer satisfaction.

Table 3. Summary of control variables effect in the structural model analysis

\begin{tabular}{lcc}
\hline \multicolumn{1}{c}{ Control Variable } & Standardized Estimates & Sig \\
\hline Hotel star $\rightarrow$ service guarantees & 0.241 & 0.000 \\
Hotel star $\rightarrow$ customer satisfaction & 0.089 & 0.039 \\
\hline
\end{tabular}

\subsection{Relationship between Hotel Star and Service Guarantees}

Hotel star were found to be significantly different on service guarantees. The standardized estimates derived from the final structural model has shown that hotel category has significantly associates with service guarantees $(\mathrm{r}=0.241, \mathrm{p}=0.000)$. This value denotes that hotel star, that is four-and five-star may have a significant different impact on service guarantees offered by the organization.

\subsection{Hotel Star and Customer Satisfaction}

Similarly, hotel star were also found to be significantly different on customer satisfaction. The result of the standardized estimates derived from the final structural model has shown that hotel category has marginally significant impact on customer satisfaction $(r=0.089, p=0.039)$. The marginal result showed that customer has almost the same level of either satisfaction when staying at four or five-star hotel in this country as the two hotels category offers similar type of services and facilities in their service offerings.

\section{Discussion and Conclusions}

Good service is an essential asset to upscale or luxury hotels. An assumption is that four and five-star hotels are committed to provide service that will delight the customers. In a similar vein, service guarantees can assist hotels to achieve superior service quality through the management commitment and its employee participation to ensure the consistency of service delivery.

The study found that the front-line employees perceived that hotel star do have significant difference in terms of relationship with service guarantees. It shows that four-star and five-star hotels have some level of service differences offered to customer. Employees in five-star hotel might perceive that they offer higher level of service guarantees and committed to service excellent and do not compromise with service mistakes. Learning from previous service failures is vital to create a long-term relationship with the customers, thus employees committed to provide efficient service recovery and take proactive action to prevent repeat service breakdown. Therefore, service failure is minimal and customers have higher level of satisfaction when staying in five-star hotel.

On the other hand, four-star hotel employees might feel that they have meet customer expectation and achieved 
customer's satisfaction. The employees believed that service guarantees guide them to act and serve the customers accordingly. They believe that they can improve the service especially when they receive comment or feedback from customers as service guarantees act as service improvement in future. Nevertheless, based on the result of the study, it can be said that the service guarantees offer in five-star hotel might be more meaningful and have higher credibility compared to the service guarantees offer in four-star hotel in Malaysia.

In terms of hotel star and customer satisfaction, the result shows that employees assumed that customers might perceive that four-star and five-star hotel offer almost the same service level and facilities. Customers might find it quite difficult to differentiate the level of service offering as most of the customer's actual experience met the expectation and they satisfied with the services offered by both types of hotel. Employees may perceived that customers may find the facilities such as hotel rooms, restaurant and outdoor facilities are quite similar in both four and five-star hotels thus the level of satisfaction is almost similar. However, the key differences in the service delivery could be the performance and dedication of hotel employees in serving the guest.

\section{Practical Implication}

The findings of the study have some implication to the hotel sector, particularly the top management who usually formulate policies, rules and regulation and also to the middle managers who practice and implement them. The findings show that there is a significant relationship between hotel star and service guarantees. Clear information, knowledge and awareness among employees are important to ensure employees know what is expected from them and able to perform accordingly. Employees should be encouraged to give honest feedback about matter concerning their work, free of giving suggestions on the improvement on the overall service performance and management should tolerate dissent.

The study also found that there is a marginal relationship between hotel star and customer satisfaction. Thus, managers play an important roles in encouraging its employees to deliver consistent and reliable service to customers to enhance the perception among customers who consumed the service. Managers also facilitate, coach and giving guidance rather than use of control and command technique (Ayup \& Chung, 2010). Employees appreciate if they are given the freedom to perform as they will be more motivated and flexible in delighting the customers. Managers should also provide regular feedback to employees about customer comment and work related issues so they can continuously improve. Luxury hotels required dedicated and motivated employees, therefore the encouragement and support from management and peers will persuade the employee's interest to perform and act diligently.

\section{Recommendation for Future Research}

Further studies should be conducted in different hotel categories such as in three star hotel. A comparative study among employees in different industries such as fast food could be conducted in addition to studying the relationship between other control variables selected in the demographic factors.

\section{Conclusion}

To the hotel managers and practitioners, it is important for the managers to pay attention to how they manage their employees, particularly those who work on the front line as they are in a critical position to represent the organisation. As service guarantees serve as important guidelines, managers must ensure that employees follow the rules and procedures during service transaction and they honoured the service guarantees either it is explicit or implicitly display. The managers must also acknowledged that customer appreciate service guarantees as they signal the quality of a hotel and increase their purchase intentions because customers believe that they have made a better choice by staying with a service provider with higher credibility, thus hotels must be able to keep their reliable service promise. Customers also believed that in the case of service failures, luxury hotel would treat them fairly. Therefore, it is the managers and the hotels' responsibility to promote the culture of customer satisfaction among employees.

\section{References}

Aaker, D. A., Kumar, V., \& Day, G. S. (2001). Marketing Research (7th ed.). New York: John Wiley and Son Inc.

Ayupp, K., \& Chung, T. H. (2010). Empowerment: Hotel employees' perspective. Journal of Industrial Engineering and Management, (3), 561-575.

Aziz, Y. A. (2007). Empowerment and Emotional Dissonance: Employee-Customer Relationships in The Malaysian Hotel Industry. Unpublished doctoral dissertation, Nottingham University, United Kingdom.

Berry, L., Parasuraman, A., \& Zeithaml, V. (1994). Improving Service Quality in America: Lessons Learned. The Academy of Management Executive, 8(2), 32-52. 
Cronin, J. J., \& Taylor, S. A. (1992). Measuring service quality: A reexamination and extension. Journal of Marketing, 56(July), 55-68. http://dx.doi.org/10.2307/1252296

Firnstahl, T. W. (1989). My employees are my service guarantee. Harvard Business Review, (July-August), 28-32.

Gronroos, C. (2007). Service Management and Marketing (3rd ed.). West Sussex: John Wiley.

Guzzo, R. (2010). Customer Satisfaction in the Hotel Industry: A Case Study from Sicily. International Journalof Marketing Studies, 2(2), 3-12.

Hart, C. (1988). The power of unconditional service guarantees. Harvard Business Review, (July-August), 54-62.

Hays, J. M., \& Hill, A. V. (2006). Service guarantee strength: The key to service quality. Journal of Operations Management, 24, 753-764. http://dx.doi.org/10.1016/j.jom.2005.08.003

Jones, T. O., \& Sasser, W. E. (1995). Why satisfied customers defects. Harvard Business Review, 73(6), 88-99.

Kandampully, J., \& Suhartanto, D. (2003). The role of customer satisfaction and image in gaining customer loyalty in the Hotel Industry. Journal of Hospitality \& Leisure Marketing, 10(1), 3-25. http://dx.doi.org/10.1300/J150v10n01_02

Kashyap, R. (2001). The effects of service guarantees on external and internal markets. Academy of Marketing Science Review, 5(8), 1-19.

Kim, T., Kim, W. G., \& Kim, H. B. (2009). The effects of perceived justice on recovery satisfaction, trust, word-of-mouth, and revisit intention in upscale hotels. Tourism Management, 30(1), 51-62. http://dx.doi.org/10.1016/j.tourman.2008.04.003

Kivelä, J. J., \& Chu, C. Y. H. (2001). Delivering quality service: Diagnosing favorable and unfavorable service encounters in restaurants. Journal of Hospitality \& Tourism Research, 25(3), 251-271. http://dx.doi.org/10.1177/109634800102500302

Krejcie, R. V., \& Morgan, D. W. (1970). Determining Sample Size for Research Activities. Educational and Psychological Measurement, 30, 607-610.

Li, X., \& Krit, J. (2012). Service Is Power: Exploring Service Quality in Hotel's Business, Yunnan, China. International Business Research, 5(5), 35-50. http://dx.doi.org/10.5539/ibr.v5n5p35

Liden, S. B., \& Skalen, P. (2004). The effect of service guarantees on service recovery. International Journal of Service Industry Management, 14(1), 36-58. http://dx.doi.org/10.1108/09564230310465985

Lovelock, C., \& Wirtz, J. (2007). Services Marketing: People, Technology, Strategy (6th ed.). United States: Pearson Education.

McDougall, G. H. G., Levesque, T., \& Plaat, P. V. (1998). Designing the service guarantee: unconditional or specific? Journal of Services Marketing, 12(4), 278-293. http://dx.doi.org/10.1108/08876049810226955

Reichheld, F. F., \& Sasser, J. (1990). Zero Defections: Quality Comes to Services. Harvard Business Review, $105-111$

Severt, D. E. (2002). The customer's path to loyalty: A partial test of the relationships of prior experience, justice, and customer satisfaction. Unpublished doctoral dissertation, Virginia Polytechnic Institute and State University.

Shemwell, D. J., Yavas, U., \& Bilgin, Z. (1998). Customer-service provider relationships: An empirical test of a model of service quality, satisfaction and relationship-oriented outcomes. International Journal of Service Industry Management, 9(2), 155-168. http://dx.doi.org/10.1108/09564239810210505

Söderlund, M. (1998). Customer satisfaction and its consequences on customer behaviour revisited. International Journal of Service Industry Management, $9(2), \quad$ 169-188. http://dx.doi.org/10.1108/09564239810210532

Spreng, R., Harrell, G., \& Mackoy, R. (1995). Service recovery: Impact on satisfaction and intentions. Journal of Services Marketing, 9(1), 15-23. http://dx.doi.org/10.1108/08876049510079853

Suki, N. M. (2012). Examining Hotel Service Quality Elements Effects on Overall Tourist Satisfaction. European Journal of Social Sciences, 30(4), 664-653.

Wirtz, J., Kum, D., \& Lee, K. S. (2000). Should a firm with a reputation for outstanding service quality offer a service guarantee? Journal of Services Marketing, 14(6), 502-512. 
http://dx.doi.org/10.1108/08876040010347615

Zeithaml, V., Bitner, M. J., \& Gremler, D. D. (2009). Services Marketing: Integrating Customer Focus Across The Firm (5th ed.). New York: McGrawHill.

\section{Copyrights}

Copyright for this article is retained by the author(s), with first publication rights granted to the journal.

This is an open-access article distributed under the terms and conditions of the Creative Commons Attribution license (http://creativecommons.org/licenses/by/3.0/). 